\title{
EPISTEMOLOGI PEMBAHARUAN USUL FIKIH HASAN TURABI
}

\author{
Mas'adah, M.Hi.,M.Pd.I. \\ Dosen Stit Raden Wijaya Mojokerto \\ masadah789@gmail.com
}

\begin{abstract}
The article is the research result of the reform of Ushul Al Fiqh proposed by Hasan Turabi.The method applied is descriptive qualitative, exposing the entire ideas of Hasan Turbi pertaining to the reform of Ushul Fiqh and proceeded by the approach of content analysis. The next step is to make comparison with ideas of other Ushul Fiqh scholars. The reform of Ushul Fiqh according to HasanTurbi is to implement qiyas al - wasi ( wide qiyas) and istishab al-wasi (wide qiyas). The method applied by Hasan Turbi has already been used by former Ushul Fiqh scholars. Hasan Turbi only adds the words al - wasi . The essence of qiyas al - wasi and istishab al -wasi by Hasan Turabi is traditional issues already been done for a long time in a certain community or actual issues.
\end{abstract}

Keywords: Tajdid, al-Qiyās wāsi,", Istishāb al-Wāsi.

\begin{abstract}
Abstrak
Artikel inimerupakan hasil penelitian dari reformasi Ushul Al Fiqh yang diajukan oleh Hasan Turabi. Metode yang digunakan adalah deskriptif kualitatif, mengungkap keseluruhan gagasan Hasan Turbi yang berkaitan dengan reformasi Ushul Fiqh dan dilanjutkan dengan pendekatan analisis isi. Langkah selanjutnya adalah membandingkannya dengan gagasan para ilmuwan Ushul Fiqh lainnya. Reformasi Ushul Fiqh menurut Hasan Turbi adalah menerapkan qiyas al-wasi (qiyas lebar) dan istishab al-wasi (qiyas lebar). Metode yang diterapkan oleh Hasan Turbi telah digunakan oleh mantan sarjana Ushul Fiqh. Hasan Turbi hanya menambahkan kata al-wasi. Inti dari qiyas al-wasi dan istishab al-wasi oleh Hasan Turabi adalah isu-isu tradisional yang sudah lama dilakukan dalam masyarakat tertentu atau isu aktual.
\end{abstract}

Kata Kunci: Tajdid, al-Qiyās wāsi', Istishāb al-Wasi.

\section{A. Pendahuluan}

\section{Latar Belakang}

Sumber hukum Islam yang paling mendasar pada tahap awal perkembangan Islam adalah al-Qur'an, yang kemudian diperinci dan ditafsirkan oleh al-Sunnah. Pada tahap selanjutnya, setelah Rasulullah wafat dan permasalahan hukum semakin meningkat,Teori hukum Islam atau disebut 


\section{Mas'adah}

juga ushul al fiqh ${ }^{1}$ adalah salah satu disiplin ilmu keislaman tradisional yang memiliki posisi sangat penting dalam pengembangan hukum Islam. Dalam disiplin ilmu ini paradigma tentang keilmuan dan kaidah-kaidah sangat diperlukan sebagai pijakan dasar formulasi pembentukan hukum islam yang mana salah satunya adalah qiyas dan istishab ${ }^{2}$ yang digunakan oleh beberapa sahabat Rasul ketika tidak menemukan dalam al Qur'an dan al sunnah diantaranya Abu Bakar, Umar, Utsman, Ali, Ibn Abbas, Ibn Mas'ud, Ubay ibn Ka'ab, Zaid ibn Sabit, Abu Musa al-Asy'ary ${ }^{3}$ sebagaimana merujuk kasus Muaz bin Jabal ${ }^{4}$

Dalam sketsa pemikiran hukum dikenal bahwa qiyas merupakan suatu metode penetapan hukum yang menempati posisi ke empat dalam kerangka pemikiran hukum (ushul fiqh). Qiyas merupakan titik masuk pertama dalam pintu ijtihad. Al-Mazini rekan Imam Syafi'i, menyatakan : "Para ahli fikih sejak masa Rasulullah saw sampai masa kita sekarang dan seterusnya sama-sama menggunakan qiyas ".2 Para ulama menilai bahwa semua produk hukum fiqh

\footnotetext{
${ }^{1}$ Usul Fiqh adalah pengetahuan kaedah-kaedah yang menyampaikannya kepada istinbāt hukum syara,, yang furū,,melalui dalil-dalil yang terperinci lihat Muhammad ibn Alī ibn Muhammad asy-Syawkān̄̄,Irsyād alFuhūl(Beirut:Dār al-Kutub al-,,Arabiyah,t.t.),.Sedangkan fikih ialah ilmu yang berhubungan dengan hukum syara, yang diamalkan yang diambil dari dalil-dalil yang tafsīliyah sebagai produk dari ushul fiqh lihat Muhammad Abū Zahrah, Usūl al -Fiqh(Kairo:Dār al-Fikr al-,,Arabī,t.t), .5

${ }^{2}$ Muhammad Roy, Ushul Fiqih Madzhab Aristoteles: Pelacakan Logika Aristoteles dalam Qiyas Ushul Fiqih, (Yogyakarta: Safiria Insania Press, 2004), 36. Lihat juga. Muhammad Roy Purwanto, "Nalar Qur'ani alSyafi'i dalam Pembentukan Metodologi Hukum: Telaah Terhadap konsep Qiyas", dalam An-Nur: Jurnal Studi Islam, Vol. 1, No.1, September 2004.

${ }^{3}$ Muhammad Ali as-Sais, Nasy'ah al-Fiqh al-Ijtihadi wa Athwarih,(Ttp: Mujma' al-Buhus al-Islamiyah, 1970), 36-75.

${ }^{4}$ Ahmad ibn Hanbal, Musnad al-Imam Ahmad Ibn Hanbal, (Beirut: Dar al-Kutub al-Islamiyah, 1993), vol.IV, 252.
} 


\section{Epistemologi Pembaharuan Usul Fikih Hasan Turabi}

yang dihasilkan oleh metode qiyas ini benar-benar valid dan memiliki kekuatan hukum yang dapat dipertanggungjawabkan secara rasional. Imam Syafi'I membuat kualifikasi ketat unsur-unsur yang ada pada metode qiyas. Menurutnya qiyas dapat berlaku dan memiliki kekuatan hukum yang valid jika keempat syaratnya terpenuhi yaitu asl, hukm asl, far', dan illah. ${ }^{3}$

Zaman terus berkembang, kehidupan manusia terus berlangsung, begitu juga dengan permasalahan yang dihadapinya. Maka demi menjawab semua permasalahan diperlukan pembaharuan dalam agama. Dimana pintu ijtihad harus dibuka selebar mungkin, sehingga agama tidak akan menjadi doktrin yang ada dalam tataran teori dan sesuatu yang sacral dan tidak tersentuh, melainkan agama hadir sebagai tuntutan manusia. Dalam perjalanan selanjutnya banyak tokoh bermunculan guna memberikan kontribusinya dalam rangka membangunkan masyarakat yang selama ini dalam masa kemunduran dan mendambakan datangnya kembali The Golden Age Of Muslim. Di antara tokoh kontemporer yang mencoba menciptakan kembali The Golden Age Of Muslim adalah pemikir asal Sudan yaitu Hasan Turabi, yang dalam kesempatan ini, pemakalah akan membahas mengenai beberapa pemikiran beliau

\section{Rumusan Masalah}

Dalam tulisan ini penulis akan mengemukakan pendapat maupun pemikiran Hasan Al-Turabi, tentang perlunya mengadakan pembaharuan Usul Fikih. 


\section{Mas'adah}

\section{B. Pembahasan}

\section{Pengertian Pembaharuan}

Secara etimologi pembaharuan berasal dari kata :" Jaddadadan dikatakan ajadda asy-syai artinya menjadikan sesuatu itu baru. ${ }^{5}$ Secara terminologi, tajdīdberarti pembaharuan dalam kehidupan keagamaan, baik berbentuk pemikiran ataupun gerakan, sebagai reaksi atau tanggapan terhadap tantangantantangan internal maupun eksternal yang menyangkut keyakinan dan urusan sosial umat. ${ }^{6}$ Tajdid diartikan juga sebagai upaya dan aktivitas untuk mengubah kehidupan umat Islam dari keadaan yang sedang berlangsung kepada keadaan yang hendak diwujudkan dalam upaya untuk kesejahteraan (kemaslahatan hidup) umat manusia.Menurut Karen Amstrong tajdidialah gerakan pembaharuan yang berusaha memulihkan Islam ke kemurniannya dengan kembali ke Alquran dan sunnah dengan menolak legeslasi dan praktik yang

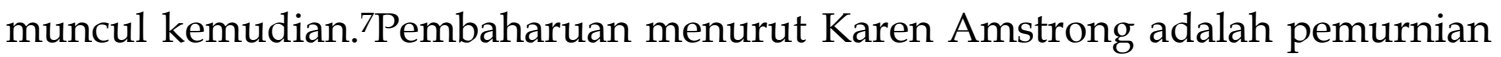
artinya kondisi umat sudah melenceng dan lari dari nilai-nilai yang sudah digariskan di dalam Alquran dan sunnah. Dengan demikian perlu adanya pemurnian ajaran Islam agar bersih dan lebih steril dari unsur-unsur yang tidak berasal dari Islam.Khusus mengenai pembaharuan usul fikih, Dr Sya, bān Muhammad „Ismā,„il megemukakan bahwa yang dimaksud dengan

\footnotetext{
${ }^{5}$ Luois Mahluf, al-Munjid Fī al-Lugah wa al-A,,lām (Beirut: Dār al-Masyriq,1986),.81

${ }^{6}$ Karen Amstrong, Berperang demi Tuhan Fundamentalisme Dalam Islam, Kristen, dan Yahudi (Bandung: PT Mizan Pustaka, 2004), .570

${ }^{7}$ Ibid
} 


\section{Epistemologi Pembaharuan Usul Fikih Hasan Turabi}

pembaharuan Usul Fikih ialah:"Merekontruksi kembali bangunan usul fikih, agar menjadi baru, dengan bentuk yang sesuai dengan kehendak zaman. ${ }^{8}$ Dengan demikian pembaharuan dalam Islam bukan berarti mengubah, mengurangi atau menambahi teks Al-Quran maupun Hadith, melainkan hanya menyesuaikan paham atas keduanya.

Dalam masalah tajdīdini, ada sebuah hadis riwayat dari Abū Dāwud, yaitu: Artinya: “Dari Abi Hurairah, ia mengatakan tentang apa yang pernah aku ketahui dari Rasulullah saw ia bersabda:" sesungguhnya Allah akan membangkitkan untuk umat ini pada setiap awal seratus tahun seseorang yangmelakukan pembaharuan agamanya. ${ }^{9}$ Dalam kaitannya dengan itulah, Harun Nasution ${ }^{10}$, mendefinisikan pembaharuan Islam sebagai "pikiran dan gerakan untuk menyesuaikan faham-faham keagamaan Islam dengan perkembangan baru yang ditimbulkan oleh pengetahuan dan teknologi modern.Dengan pengertian itu tampaknya Nasution mengidentik pembaharuan Islam dengan modernitas Islam. Kata "modern" berasal dari kata latin modo, yang berarti "masa kini" atau "mutakhir"11. Dari pengertian modern demikian definisi yang dikemukakan Nasution juga mengandung arti Islam harus mampu menjawab tantangan yang diakibatkan oleh perkembangan

\footnotetext{
${ }^{8}$ Sya,,bān Muhammad „Ismā,,ịl, at-Tajdīd Fī Usūl al-Fiqh (Mekah:Maktabah al-Makkiyah,2000),.41

${ }^{9} \mathrm{Ab} \overline{1}$ Dāwud Sulaimān ibn al-Asy,,aś as-Sijistāny al-Azd̄̄, Sunan Ab̄̄ Dāwud(Indonesia:Maktabah ahlān,t.t.), Jil IV, 109

${ }^{10}$ Harun Nasution, Pembaharuan dalam Islam, Sejarah Pemikiran dan Gerakan, Jakarta: Bulan Bintang, 1994, 11-12

${ }^{11}$ David B.Guralnik, Websters New World Dictionary of the American Language, (New York: Warners Book, 1987), 387
} 


\section{Mas'adah}

zaman.

Adapun tokoh-tokoh yang mempelopori gerakan pembaruan yang disebut dengan mujaddid antara lain : Muhammad Bin Abdul Wahhab, Syah Waliyulloh, Sultan Mahmud II, Muhammad Ali Pasha, At-Tahtawi, Jamaluddin al-Afghani, Muhammad Abduh, Muhammad Rasyid Ridha, Sayyid Ahmad Khan, dan Muhammad Iqbal. Az-Zabīdī menjelaskan bahwa mujaddiddi abad ke I „Umar ibn „Abd al-„,Azīz, abad ke II Imam asy-Syāfi,,1, abadke III AlAsy „, arī atau Ibn Suraij, abad ke IV Al-Asfāinī, As-Sa,,lūkī atau Al-Bāqilānī dan abad ke V ialah Al-Gazālī. ${ }^{12}$

\section{Landasan Pembaharuan Dalam Islam}

\section{a. Landasan Teologis}

Pertama, keyakinan bahwa Islam adalah agama universal (universalisme Islam). Sebagai agama universal, Islam memiliki misi rahmah lil al‘alamin, memberikan rahmat bagi seluruh alam. Universalitas Islam ini dipahami sebagai ajaran yang mencakup semua aspek kehidupan, mengatur seluruh ranah kehidupan umat manusia, baik berhubungan dengan hablu min Allah (hubungan dengan sang khalik), habl min al-nas (hubungan dengan sesama umat manusia), serta habl min al-'alam (hubungan dengan alam lingkungan $)^{13}$.Konsep universalisme Islam itu meniscayakan bahwa ajaran Islam berlaku pada setiap waktu, tempat, dan semua jenis manusia, baik bagi

\footnotetext{
${ }^{12}$ Muhammad ibn Muhammad al-Husainī az-Zabīdī, Ittihāf as-Sādah al-Muttaqīn( Beirut:Dār al-Kutub al-,„Imiyah, 1989 ), Jil I, 35

${ }^{13} \mathrm{Ibid}$

6 | Dinamika Vol. 3, No. 1, Juni 2018
} 


\section{Epistemologi Pembaharuan Usul Fikih Hasan Turabi}

bangsa Arab, maupun non Arab dalam tingkat yang sama, dengan tidak membatasi diri pada suatu bahasa, tempat, masa, atau kelompok tertentu. Dengan ungkapan lain bahwa nilai universalisme itu tidak bisa dibatasi oleh formalisme dalam bentuk apapun 14

Kedua, finalitas fungsi kenabian Muhammad Saw sebagai rasul Allah memunculkan keyakinan yang terpatri bahwa Islam adalah agama terakhir yang sempurna15. al-Qur'an adalah kitab yang lengkap karena mencakup segala aspek dan berhentinya fungsi kenabian bukan berarti terputusnya petunjuk Tuhan kepada umat manusia.secara fungsional, peran ulama dipandang sangat penting untuk memelihara dinamika ajaran Islam. Hal ini dipandang tidaklah berlebihan karena ulama adalah pewaris para nabi (al'ulama' waratsah al-anbiya').

\section{b. Landasan Normatif}

Landasan normatif adalah landasan yang diperoleh dari teks-teks nash, baik al-Qur'an maupun al-Hadis. Banyak ayat al-Qur'an yang dapat dijadikan

\footnotetext{
${ }^{14}$ Nurcholis madjid, Islam Doktrin dan Peradaban, Jakarta: Paramadina, 1992. Hal 360-362; Saiful Mizani, (ed), Islam rasional gagasan dan Pemikiran, frop. Drs. Harun Nasution, Bandung: Mizan, 1996, Hal. 3233. Senada dengan hal di atas, Din Syamsudin mengatakan bahwa watak universalisme Islam meniscayakan adanya pemahaman selalu baru untuk menyikapi perkembangan kehidupan manusia yang selalu berubah. Islam yang universal — shalih li kulli zaman wa makan - menuntut aktualisasi nilai-nilai Islam dalam konteks dinamika kebudayaan. Kontekstualisasi ini tidak lain dari upaya menemukan titik temu antara hakikat Islam dan semangat jaman. Hakikat Islam yang rahmah li al-'alamin berhubungan secara simbiotik dengan semangat jaman, yaitu kecondongan kepada kebaruan dan kemajuan. Selanjutnya juga dikatakan bahwa pencapaian cita-cita kerahmatan dan kesemestaan sangat tergantung kepada penemuan-penemuan baru akan metode dan teknik untuk mendorong kehidupan yang lebih baik dan lebih maju. Din Samsudin mengatakan bahwa keuniversalan mengandung muatan kemodernan. Islam menjadi universal justru karena mampu menampilkan ide dan lembaga modern serta menawarkan etika modernisasi.

${ }^{15}$ Maulana Muhammad Ali, The Religion Of Islam, Cairo: The Arab Writer Publisher \& Printers, t.t, 3
} 
pijakan bagi pelaksanaan tajdid dalam Islam di antaranya surat al-Dluha: 4 . "Sesungguhnya yang kemudian itu lebih baik bagimu dari yang dahulu", Ayat lainnya adalah surat ar-Ra'd: 11, "Sesungguhnya Allah tidak akan mengubah apa yang ada pada suatu kaum sehingga mengubah apa yang ada dalam diri mereka sendiri"mengubah disini meliputi pola pikirnya maupun perilakunya.kekuatan-kekuatan pembaru dalam masyarakat harus selalu ada sehingga masyarakat dapat melakukan mekanisme penyesuaian dengan derap langkah dinamika sejarah.

Sementara itu, dalam hadis Nabi terdapat teks hadis yang menyatakan bahwa "Allah akan mengutus kepada umat ini pada setiap awal abad seseorang yang akan memperbarui (pema-haman) agamanya". Menurut Achmad Jainuri, dikalangan para pakar terdapat perbedaan interpretasi mengenai kata 'ala ra'si kulli mi'ati sanah (setiap awal abad) ini berkaitan dengan saat munculnya sang mujaddid. Sebagian lain mengkaitkan dengan tanggal kematian. Hal ini sesuai dengan tradisi penulisan biografi dalam Islam yang biasanya hanya menunjuk tanggal kematian seseorang. Atas dasar ini, maka sebagian lagi memahami dalam pengertian yang lebih longgar dan menyatakan bahwa yang penting mujaddid yang bersangkutan hidup dalam abad yang dimaksud. Terlepas dari adanya perdebatan yang jelas bahwa ide tajdid dalam Islam memiliki landasan normatif dalam teks hadith Nabi. 


\section{Epistemologi Pembaharuan Usul Fikih Hasan Turabi}

\section{c. Landasan Historis}

Ketika Nabi Muhammad saw. masih hidup dan pengikutnya masih terbatas pada bangsa Arab yang berpusat di Makkah dan Madinah, Islam diterima dan dipatuhi tanpa bantahan. Dalam perkembangannya, Islam baik secara etnografis maupun geografis menyebar luas, dari segi intelektual pun membuahkan umat yang mampu mengembangkan ajaran Islam itu menjadi berbagai pengetahuan, mulai dari ilmu kalam, ilmu hadis, ilmu fikih, ilmu tafsir, filsafat, tasawuf, dan lainnya, terutama dalam masa empat abad semenjak ia sempurna diturunkan. Umat Islam dalam periode itu dengan segala ilmu yang dikembangkannya, berhasil mendominasi peradaban dunia yang cemerlang, sampai mencapai puncaknya di abad XII-XIII M, di masa inilah, ilmu pengetahuan ke-Islaman berkembang dan para pemikir muslim sampai puncaknya, baik dalam bidang agama maupun dalam bidang non agama.

Setelah lima abad sampai ke puncak kejayaannya, Islam menjadi statis atau dikatakan mengalami kemunduran. Pintu ijtihad dinyatakan tertutup digantikan dengan taklid yang merajalela sampai pada abad ke XVIII'16Meskipun demikian, upaya pembaruan senantiasa terjadi, di mana dalam suasana seperti digambarkan di atas, yaitu sejak abad XIII M (peralihan ke abad XIV M) Ibn Taimiyah telah tampil membendung-nya (melakukan

\footnotetext{
${ }^{16}$ Harun Nasution, Pembaharuan dalam Islam, Sejarah Pemikiran dan Gerakan, Jakarta: Bulan Bintang, 1994) 11
} 
pembaruan). ${ }^{17}$

Gerakan pembaharuan pra-modern (pasca Ibnu Taimiyah), mengambil bentuknya terutama pada abad XVII dan XVIII M. Sementara itu, gerakan modern terutama dimulai pada saat jatuhnya Mesir di tangan Napoleon Bonaparte (1798-1801 M), yang kemudian menginsafkan umat Islam tentang rendahnya kebudayaan dan peradaban yang dimilikinya, serta memunculkan kesadaran akan kelemahan dan keterbelakangan ${ }^{18}$.

\section{Biografi Hasan Al-Turabi}

Dr Hasan Al-Turabi lahir di Kassala, Sudan Timur, pada tahun 1932, dari keluarga yang memiliki tradisi panjang dalam pengajaran Islam dan sufisme. Dia tamat dari Fakultas Hukum Universitas Khartoum pada 1955, menyelesaikan pendidikan S-2 dalam bidang Hukum di London. Pada tahun 1957, ia memperoleh gelar Ph.D, dalam bidang Hukum Tata Negara dari Universitas Sorbonne, Paris pada tahun 1964.Selama ia menetap di Prancis, antara tahun 1959 hingga 1964, dia pernah melakukan kunjungan ke Amerika19.Dr Hasan Al-Turabi menjadi Dekan Fakultas hukum universitas Khartoum, jabatan yang kemudian ditinggalkannya ketika dia menjadi anggota

\footnotetext{
${ }^{17}$ Pembaruan yang dilakukan oleh Ibnu Taimiyah, ditujukan kepada tiga sasaran utama yaitu, sufisme, filosof yang mendewakan rasionalisme, teologi asy'ariyah yang cenderung pasrah kepada kehendak Tuhan dan totalistik. Ketiganya dipandang sebagai menyimpang dari ajaran Islam sehingga di dalam memberikan kritik selalu dibarengi seruan kepada umat Islam agar kembali kepada al-Qur'an dan Sunnah serta memahaminya Lihat : M. Amin Rais, "Kata Pengantar", dalam Jhon J Donohue dan Jhon L. Esposito (eds), Islam dan Pembaharuan: Ensiklopedi Masalah-masalah, terj. Machnun Husein. Jakarta: Rajawali Press, 1993, Hal. ix

${ }^{18}$ Harun Nasution, Pembaharuan dalam Islam, Sejarah Pemikiran dan Gerakan, Jakarta: Bulan Bintang, 1994, h. 14; Julbadri Idris, Pembaharuan Islam pada masa periode Modern, dalam Jurnal media Dinamika, No. 29 tahun XIV/ 1998), 56

${ }^{19}$ Hasan al-Turabi, Fiqih Demokratis, terj. Abdul haris dan Zimul Aim, (Jakarta, Arasy, 2003), 11
} 


\section{Epistemologi Pembaharuan Usul Fikih Hasan Turabi}

parlemen dan Sekretaris Jenderal Islamic Charter pada Desember 1964.

Pada tahun 1969, setelah berlangsungnya upaya kudeta oleh kaum kiri, untuk pertama kalinya dia mendekam di penjara Sudan hingga tahun 1977, tahun ketika ia memilih Perjanjian Rekonsiliasi Nasional dengan Nameiri. Dia menjadi jaksa Agung dari tahun 1979 hingga 1982, dan menjadi kepala penasehat masalah-masalah hukum dan luar negeri hingga Maret 1985. Dia dan pemuka-pemuka gerakan Islam lainnya kemudian dijebloskan ke penjara, dan hanya dibebaskan ketika rezim Nomeiri jatuh. ${ }^{20}$ Pada tahun 1988, Front Nasional Islam (NIF) yang dipimpin oleh Hasan Turabi berkoalisi dengan pemerintahan Shadiq Al-Mahdi dan mengantarkannya menjadi jaksa agung, lalu deputi perdana menteri dan menteri luar negeri. Dia pernah menjabat Sekretaris Jenderal Kongres Islam Khartoum yang beranggotakan partai-partai, kelompok-kelompok, dan tokoh-tokoh gerakan nasionalis Islam yang berasal dari 55 negara Islam dan Barat. Sejak pemilu tahun 1966, dia menjabat sebagai ketua parlemen, kedudukan kedua yang paling berkuasa di negerinya, sesudah presiden yang dijabat oleh jenderal Umar Al-Basyir, juniornya di partai NIFHasan Al-Turabi selain seorang yang sibuk dan aktif di berbagai organisasi, baik di dalam pemerintahan negara Sudan ataupun dalam grup-grup dan organisasi sosial lainnyayang bersifat nasional maupun internasional, dia aktif

\footnotetext{
${ }^{20}$ Hasan Al-Turabi, Fiqih Demokratis, Terj Abdul Haris dan Zainul Am (Bandung:Arasy ,2003), 12 dan Moh.Hatta, "Pemikiran Hukum Islam Hasan Al-Turabi", Darussalam Jurnal Pendidikan, Komunikasi, dan Pemikiran Hukum Islam UIN Sunan Ampel Surabaya, No.1 Vol 7, (September 2015), hlm. 189, kolom 1.
} 


\section{Mas'adah}

juga menulis berbagai karya ilmiah, yang diantaranya adalah satu artikel tentang "The Islamic State" (Negara Islam), dansebuah buku dengan yang berjudul Tajdīd Usul al-Fiqh al-Islāmī.

Hasan Turabi dipandang sebagai tokoh gerakan Islam internasional dan salah seorang pemikir yang terkemuka. Kontribusi karya-karyanya dalam pemikiran Arab hingga Islam modern berawal dari Women In Islam dan The Prayer yang terbit diakhir 1960-an, dan The Islamic Movement In Sudan (1989). Disamping itu karyanya yang berbahasa Arab diantaranya Al-Iman wa Atsaruha fi Al-Hayat, Al-Muslim Baina Al-Wujdan wa Al-Sultan., Tajdid AlFikr Al-Islami dan Al- Wihdah wa Al-Dimukrattiyah wa Al-Fann dan Qadaya at-Tajdid. Adapun makalahnya tentang kaum perempuan dan kedudukan komunitas non muslim di negara-negara Islam telah diterjemahkan dan diterbitkan dalam bahasa Inggris. Dia juga menyumbang satu bab tentang negara Islam untuk Islam and Development, sebuah buku yang disunting oleh John L Esposito. Semasa di penjara dia menyelesaikan The Political Vocubulary Of Islam ${ }^{21}$

\section{Pemikiran Hasan Turabi}

\section{a. Usul al Din}

Keadaan agama sejak disyariatkan oleh Allah senantiasa mengalami

\footnotetext{
${ }^{21}$ Moh.Hatta, "Pemikiran Hukum Islam Hasan Al-Turabi”, Darussalam Jurnal Pendidikan, Komunikasi, dan Pemikiran Hukum Islam UIN Sunan Ampel Surabaya, No.1 Vol 7, (September 2015), hlm. 189, kolom 1.
} 


\section{Epistemologi Pembaharuan Usul Fikih Hasan Turabi}

pembaharuan yang menghubungkan yang awal dengan yang terakhir, meskipun risalah-risalah silih berganti datang mengisahkan risalah sebelumnya dan memberikan kabar gembira tentang risalah sesudahnya serta membangun kebenaran yang tetap diatas dasar-dasarnya. Dan ketika Allah menyempurnakan pengajaran manusia, sejarah memelihara risalah yang terakhir dengan syari'at yang lengkap dan abadi. ${ }^{22}$

Selama ini pembicaraan yang berkenaan syar 'u man qoblana hanya terpaku pada deskripsi tentang perbedaan pendapat seputar kehujjahannya dalam hukum- hukum, sebab syari'at yang terdahulu merupakan permulaan bagi gerakan kita menuju Allah. Oleh karena itu, Rasulullah saw berpegang pada apa yang beliau ketahui dari syari'at itu, sehingga datanglah wahyu yang membenarkan. Di dalam pembenaran, ada pembaruan yang menghidupkan kekuatan lama yang masih menjadi sebab yang relevan untuk tujuan beribadah kepada Allah dan dalam penghapusan ada pembaruan yang mengembangkan sebab-sebab ibadah, dan di dalam kisahkisah ada hikmah yang dipetik dari kebaikan amal para salaf. Sebagai contoh dan teladan dan dari kejelekan amal mereka sebagai pelajaran dan nasehat sebagaimana Allah berfirman dalam surat Hud ayat 120:

"Dan semua kisah dari rasul-rasul kami ceritakan kepadamu, ialah kisah-kisah yang dengannya kami teguhkan hatimu; dan dalam surat Ini Telah datang kepadamu kebenaran serta pengajaran dan peringatan bagi

\footnotetext{
${ }^{22}$ Ibid, hlm 192
} 
orang-orang yang beriman." 23

Pada dasarnya dalam memahami al-Qur'an tidaklah sempurna kecuali dengan mengkaji kembali syari'at-syari'at umat terdahulu, dan melalui kajian yang lengkap mengenai as-Sunnah yang menjelaskan dengan ucapan dan amal perbuatan Nabi Muhammad saw. Memahami Sunnah nabi tidaklah cukup hanya mengkaji hadis-hadis yang sampai kepada Rasulullah saw saja, sebab amalan para sahabat adalah perpanjangan tangan yang tidak terputus dari masa penurunan wahyu, bahkan kemajuan ke arah yang sama dengan sunnah yang perlu dipelajari, agar sunnah dapat dipelajari dengan baik. Dengan demikian, kita tidak bisa memahami masa lalu kecuali dalam konteks masa yang datang setelahnya.Dalam perjalanan sejarah ada kaum konservatif yang memandang masa lalu sebagai warisan yang didalamnya terkandung solusi yang cukup memadai bagi seluruh tantangan baru. Menurut mereka tidak ada jalan lagi untuk mengadakan pembaruan dalam urusan agama, kemajuan agama telah terhenti pada usaha ulama salaf, kebebasan ijtihad terhapus di dalam pandangan generasi selanjutnya. Dengan demikian kebebasan agama telah dibatasi dalam ruang dan waktu tertentu di masa lalu

Pada dasarnya, dalam memahami al-Qur'an tidaklah sempurna kecuali dengan mengkaji kembali syari'at-syari'at umat terdahulu, dan

\footnotetext{
${ }^{23}$ Departemen Agama RI, Al-Qur'an dan Terjemahnya, (Jakarta: Maghfirah Pustaka, 2006), 235
} 


\section{Epistemologi Pembaharuan Usul Fikih Hasan Turabi}

melalui kajian yang lengkap mengenai as-Sunnah yang menjelaskan alQur'an dengan ucapan dan amal perbuatan Nabi Muhammad Saw. Memahami sunnah nabi tidaklah cukup hanya mengkaji hadith-hadith yang samapada Rasulullah Saw., saja, sebab amalan para sahabat adalah perpanjangan tangan yang tidak terputus dari masa penurunan wahyu, bahkan kemajuan ke arah yang sama dengan sunnah yang perlu dipelajari agar sunnah dapat dipelajari dengan baik. dengan demikian, kita tidak bisa memahami masa lalu kecuali dalam konteks masa yang datang setelahnya. Dari sini muncullah kesatuan umat Islam sepanjang sejarah karena mereka merupakan rangkaian yang bersambung dan menuju kepada konsep-konsep keagamaan yang sama. ${ }^{24}$

\section{b. Kebutuhan terhadap Metodologi Usul Fikih}

Ilmu ushul fiqh telah menorehkan sejarahnya melalui perjalanan panjang yang cukup mengesankan dalam penentuan arah dan dinamika perubahan masyarakat. ilmu ini juga telah memberikan corak yang jelas bagi peradaban Islam dalam berbagai aspek kehidupan. Telah banyak pemikiran besar yang mencoba menggali sejumlah aturan dan kaidah fiqh dari berbagai teks wahyu. Para Juris Islam yang dikomandani oleh Imam alSyafi'i telah berupaya mengukuhkan ilmu ushul fiqh baik secara partikular

\footnotetext{
${ }^{24}$ Hasan al-Turabi, Qadaya al-Tajdid: Nahwu Minhaj Usuli, Ma'had lil Buhus wa al-Dirasah alIjtima'iyyah, t.t, 80
} 
maupun universal sehingga ummat merasa yakin bahwa tidak ada satu celah pun yang tidak tersentuh oleh ilmu ini. ${ }^{25}$ Metode istinbat hukum yang tersebut di dalam buku-buku Usul Fikih baik klasik ataupun yang modern yang beredar di kalangan umat Islam secara umum hampir seluruhnya menunjukkan kesamaan. Urgensi pengembangan pemikiran metodologi usul fikih dalam konteks relevansinya dengan kebutuhan masyarakat Islam modern sangat mendesak.Islam sebagai agama yang dinamis, dituntut uantuk memecahkan berbagai persoalan modern secara lebih mendalam setelah sebelumnya mempfokuskan diri pada prinsip-prinsip agama dan banyak menghasilkan masalah furūiyah.Ilmu-ilmu rasional modern telah mengalami perkembangan sangat pesat. Hasan Turabi berpendapat bahwa pada saat ini perlu mengkaji kembali usul fikih dalam konteks hubungan dengan realitas kehidupan karena produk usul fikih klasik masih bersifat abstrak, wacana, dan hanya masih seputar teoritis, yang tidak mampu melahirkan fikih dan justru melahirkan perdebatan yang kunjung tidak selesai. Padahal, fikih dan usul fikih semestinya terus berkembang dalam menghadapi tantangan realitas kehidupan modern. ${ }^{26}$ Oleh karena itu, sudah selayaknya kaum muslim mengkaji kembali fikih Islam dengan persepsi baru, memanfaatkan segala ilmu sebagai sarana ibadah kepada Allah, dan

\footnotetext{
${ }^{25}$ A.Yazid, "Epistimologi Ushul Fiqh:Antara Pembaharuan dan Pemberdayaan Mekanisme Istinbath AlAhkam”, Jurnal Asy-Syir'ah,No.1 Vol.45, 2011, hlm 1028, kolom 14.

${ }^{26}$ Nawir Yuslem, Gerakan Hasan Turabi Tentang Tajdīd Usūl Al-Fikih,dalam Analytica Islamica(Vol.3 No.1, Mei 2001).106
} 


\section{Epistemologi Pembaharuan Usul Fikih Hasan Turabi}

membuat format baru yang menyatukan antara ilmu tekstual dan ilmu rasional yang selalu mengalami pembaruan dan kesempurnaan lewat eksperimentasi dan observasi.

Untuk menyelesaikan masalah-masasalahyang berkembang dimasyarakat modern saat ini,Hasan Turabi menawarkan sebuah metodologi yang dapat diterima oleh semua orang, yaitu metodologi integratif. Selanjutnya Hasan Turabi menjelaskan, bahwa pada saat sekarang ini kebutuhan metodologi Usul Fikih yang dapat dijadikan landasan untuk kebangkitan Islam sudah sangat mendesak. Disamping itu Usul Fikih yang tradisional yang selama ini kita jadikan acuan untuk beristinbat, sudah tidak relevan lagiuntuk menyahuti kondisi zaman yang sudah modern. Lagi pula secara historis Usul Fikih klasik dengan seperangkat kaedah-kaedahnya dipengaruhi oleh watak problematika fiqih yang menjadi pembahasan fikih pada waktu itu. ${ }^{27}$

Metodololgi usul fikih memiliki keluasan dan standar yang beragam sesuai dengan jenis persoalan cabang yang ditinjau. Ada persoalan fikih yang sifatnya ubudiah dan ritual kepada Allah, seperti salat, puasa, dan haji. Hukum-hukum mengenai masalah ibadah ini telah diperinci secara detail dalamberbagai nas atau teks yang sangat banyak sehingga ruang lingkup ijtihad menjadi terbatas sekali dalam masalah ini, dan pemahaman para ahli

27،Abd as-Salām al-Balājy,Tatawwur 'Ilm Usul al-Fiqh wa Tajaddudahu(T.t.p: Dār al-Wafā, 2007/1428) .262

Dinamika Vol. 3, No. 1, Juni 2018 | 17 
fikih hanya sekedar menghimpun berbagai nas itu dan menghubungkannya dengan nas lain, hingga membentuk gambaran utuh tentang ibadah. Dengan demikian, persoalan usul fikih hanya berkisar pada soal penafsiran maupun interpretrasi nas, umpamanyamengkaji masalah „ām dan khās, ta „ārud, tarjīh, mafhūm mukhālafah, mafhūm muwāfaqahdan lain-lain.Pola fatwa hanya seputar masalah furū,,, dan sedikit sekali ulama yang menulis kitabkitab tentang metodologi teoritis. Karenanya, kebanyakan fiqih berorientasi kepada persoalan-persoalan yang berkaitan individual dan ibadah ritual, seperti, perkawinan, talak, dan sebahagian besar nasnya tidak banyak menimbulkan perbedaan pendapat.Kehidupan umat Islam pada masa ini, telah banyak menyimpang jauh dari tujuan Islam, terutama dalam persoalan-persoalan kehidupan publik.Hasan Turabi mengemukakan, bahwa fikih yang memperhatikan persoalan tujuan kehidupanpublik dan kemaslahatan khususnya aspek sosial tidak dikembangkan sedemikian rupa, disebabkan oleh kondisi dan situasi yang melingkupi pertumbuhan fikih dan perkembangan kehidupan Islam waktu itu. fatwa yang selama ini diberikan hanya berkisar pada persoalan bagaimana melakukan transaksi jual beli, sementara persoalan-persoalan kebijakan umum ekonomi, seperti mengatur kehidupan masyarakat dalam bidang produksi, impor, ekspor, dan mengatasi mahalnya kehidupan atau rendahnya beban hidup, belum diperhatikan oleh pemegang otoritas persoalan, serta belum ditanyakan 


\section{Epistemologi Pembaharuan Usul Fikih Hasan Turabi}

kepada para ahli fikih untuk dituangkan dalam bidang fikih yang seharusnya.Begitu pula, persoalan-persoalan politik berikut aturan-aturan praktisnya, seperti bagaimana musyawarah dilakukan dalam masyarakat, kristalisasi ijmak, dan bagaimana bentuk pemerintahan, ketaatan serta kepemimpinan umum secara global, belum banyak dipertanyakan.Demikian juga nas-nas agama dalam bidang kehidupan publik ini lebih sedikit jumlahnya.

Hasan Turabi menawarkan beberapa konsep yang menurutnya dapat menyelesaikan berbagai permasalahan kehidupan umat masa kini, yaitu Penggunaan al-Qiyās al-Wāsi(qiyas yang luas dan konprehensif)Menurut Hasan Turabi, bahwa qiyas tradisional, yaitu yang diwariskan oleh ulama terdahulu, jangkauannya sangat terbatas dan sifatnya kaku. Qiyas serupa itu, dalam pandangannya dapat dipergunakan untuk merumuskan hukumhukum yang berkaitan dengan masalah perkawinan, moral dan masalahmasalah keagamaan lainnya. Sedangkan untuk tujuan-tujuan yangsifatnya lebih umum dan lebih luas lagi, maka qiyāsal-fitri(qiyas murni) atau qiyas yang lebih luas dan konprehensiflah yang lebih sesuai dan dibutuhkan, karena qiyas yang demikian tidak terikat dengan perasyaratan-persyaratan yang murni yang ditetapkan oleh para ahli logika Yunani, yang selanjutnya diadopsi oleh ulama Islam dalam merumuskan hukum-hukum Islam.Konsep qiyas yang dimaksudkan oleh Hasan Turabi yang juga 
disebutnya denganal-qiyāsal-wāsi,,tersebut, operasionalnya adalah dengan cara mempelajari sejumlah ayat-ayat Alquran atau hadis-hadis Nabi saw, kemudiandari padanya dirumuskan beberapa tujuan yang spesifik atau kemaslahatan tertentu yang dituju oleh syara, dalam hukum, dan kemudian tujuan-tujuan dan kemaslahatanyang spesifik tersebut diaplikasikan kepada permasalahan dan kondisi baru dalam perumusan hukum-hukumnya. Qiyas yang seperti ini, menurut Hasan Turabi adalah serupa dengan apa yang dilakukan oleh Khalifah Umar ibn Khattab. Qiyas ini juga dinamai dengan fiqhmasālih „ammah wāsi,,ah(fikih yang didasarkan kepada kemaslahatan umum). ${ }^{28}$ Konsepal-qiyāsal-wāsi,,, menurut Turabi, diambil basisnya dari maslahah mursalah, selain dari nas itu sendiri. Qiyas jenis ini juga dinamai dengan al-qiyās al-ijmālī al-awsa,, atau qiyāsal-maslahah al-mursalah.

Langkah-langkah untuk melakukan qiyas ini dimulai dengan mengumpulkan sejumlah nas ayat-ayat Alquran atau hadith, yang selanjutnya dirumuskan dari padanya tujuan atau maslahah tertentu dari suatu yang dikandung oleh koleksi ayat atau hadis tersebut. Selanjutnya menggunakan tujuan atau maslahah yang spesifik yang telah dirumuskan tersebut sebagai dasar dalam menetapkan hukum bagi kasus-kasus baru yang terjadi dalam situasi dan kondisi yang baru pula, tanpa harus melihat kepada bentuk dan kondisi kasus-kasus tersebut secara rinci. Hanya makna

${ }^{28}$ Muhammad bin 'Aly bin Muhammad asy-Syaukāny, Nail al-Awtār(Mesir: Muștafā al-Bāb al-Halaby, t.t),Jil IV h. 240 


\section{Epistemologi Pembaharuan Usul Fikih Hasan Turabi}

dan kemaslahatanlah yang dipertimbangkan, dan setelah itu hukum dari kasus-kasus terdahulu diaplikasikan kepada kasus yang baru, berdasarkan persamaan makna dan kemaslahatan yang dimiliki oleh keduanya. Akhirnya, dengan berpedoman kepada prosedur demikian, persoalanpersoalan baru yang dihadapi kehidupan modern ini dapat ditemukan solusinya. Hasan Turabi memberikan contoh mengenai konsepnya tentang qiyas diatas dengan mengutip sebuah hadith Nabi saw yang memuat kisah tentang seorang suami yang melakukan hubungan (jima') dengan isterinya di siang hari Ramadan, yang akibatnya puasanya menjadi batal dan dia dikenai hukuman. Akan tetapi, setelah dipelajari keadaannya, Nabi saw akhirnya membebaskan hukuman tersebut. Sabda Nabi saw:Dari Abu Hurairah r.a. telah berkata ia : "Datang seorang laki-laki kepada Nabi saw lalu ia berkata : Telah celaka aku ya Rasulullah, lalu Nabi berkata :" Apa yang membuat kamu celaka? Berkata laki-laki itu :" Aku telah mensetubuhi isteriku di siang Ramadan, lalu Nabi berkata:" Apakah engkau dapat memerdekakan seorang hamba? Berkata laki-laki itu:" Saya tidak sanggup ya Rasulullah, maka jika tidak sanggup, maka apakah engkau sanggup puasa dua bulan berturut-turut? Berkata laki-laki itu :"Saya tidak sanggup. Lalu berkata Nabi:" Apakah engkau sanggup memberi makan 60 orang miskin? Berkata laki-laki itu saya tidak sanggup lalu ia duduk, kemudian Nabi membawakan sekeranjang korma, lalu Nabi berkata:" Bersedekahlah 
dengan ini, apakah kepada orang yang lebih fakir dari kami? diantara ahli keluarga yang lebih membutuhkan adalah kami, lalu Nabi saw tertawa sampai nampak giginya kemudian ia bersabda:"Pergilah dan beri makanlah keluargamu (dengan korma tersebut). H.R.Jamaah ahli hadith. Kasus serupa ini kata Turabi, tidak akan terjadi lagi dalam bentuk dan kejadian yang persis sama, namun suatu makna tertentu dapat disimpulkan dari peristiwa tersebut.Umpamanya ini adalah suatu perbuatan yang berakibat membatalkan puasa yang hal tersebut dapat dipergunakan untuk mengukur perbuatan yang lain yang melahirkan akibat membatalkan puasa juga, seperti makan dan minum dan lain-lain.Mengenai metode ini, Turabi lebih lanjut berkomentar, bahwa metode qiyas ini bisa saja menjadi lebih luas atau lebih sempit, tergantung kepada sejauh mana kebebasannya dari persyaratan-persyaratan yang ditentukan untuk pelaksanakan qiyas tersebut dan efeknya terhadap perbaikan pembentukan hukum Islam. Qiyas maslahah mursalah adalah suatu qiyas yang lebih tinggi tingkatannya yang dipergunakan untuk meneliti dasar dari berbagai hukum, karena melalui qiyas tersebut kita dapat mengumpulkan sejumlah hukum mengenai kasuskasus tertentu, kemudian merumuskan dari hukum-hukum tersebut suatu kemaslahatan yang bersifat umum. Melalui konsep maslahat seperti ini, kita dapat menemukan jalan untuk mengatur kehidupan sejalan dengan kehendak syara, 


\section{Epistemologi Pembaharuan Usul Fikih Hasan Turabi}

\section{c. Penggunaan Istishāb yang luas (al-Istishāb al-Wāsi,}

Imam al-Ghazali mendefinisikan istishab dengan, berpegang pada dalil akal atau syara', bukan karena tidak mengetahui adanya dalil, melainkan setelah dilakukan pembahasan atau penelitian yang cermat, diketahui tidak adanya dalil yang mengubahnya. ${ }^{29}$ Iman al-Isnawy yang menyatakan bahwa “(Istishhab) adalah penetapan (keberlakukan) hukum terhadap suatu perkara di masa selanjutnya atas dasar bahwa hukum itu telah berlaku sebelumnya, karena tidak adanya suatu hal yang mengharuskan terjadinya perubahan (hukum tersebut)."30Muhammad Ubaidillah al-As'adi, istishaba dalah menetapkan hukum atas sesuatu berdasarkan dalil yang telah ada sebelumnya, dan dipandang tetap berlaku sampai adanya dalil lain yang mengubahnya ${ }^{31}$ al-Qarafy (w. 486H) -seorang ulama Malikiyah- mendefinisikan istishhab sebagai "keyakinan bahwa keberadaan sesuatu di masa lalu dan sekarang itu berkonsekwensi bahwa ia tetap ada (eksis) sekarang atau di masa datang."32

Ide tentangistishāb, jelas Turabi, adalah bahwa Islam diturunkan bukan untuk merekonstruksi kehidupan umat manusia berdasarkan kepada ketentuan-ketentuan yang sama sekali baru juga bukan untuk

\footnotetext{
${ }^{29}$ Abu Hamid al-Ghazali, al-Mustashfa Fi Ilm al-Ushul,(Beirut: Dar al-Kutub alIlmiyah, 1993), hlm. 159
}

${ }^{30}$ Abdurrahim al-Isnawy, Nihayah al-Sul syarh minhaju al-wushul, (Beirut: Dar al-Kutub al-Ilmiyah, 1999) jilid. 3, hlm. 131.

${ }^{31}$ Muhammad Ubaidillah al-As'adi, al-Mujiz Fi Ushul al-Fiqh, (Dar asSalam, 1990), 251

${ }^{32}$ Abu al-Abbas Ahmad ibn Idris al-Qarafy, Syarh Tanqih al-Fushul, (Al-Faniyah al-Muttahidah, cet. 1, 1973), 199. 
menghancurkan secara total ketentuan-ketentuan yang telah berlaku sebelumnya. Tetapi kedatangan Islam adalah untuk menjamin kesinambungan berlakunya praktik dan tradisi yang telah mapan yang sifatnya mencerminkan keadilan dan kebenaran, dan sekaligus memperbaiki serta memodifikasi praktek-praktek yang menyimpang dari keadilan. Rasulullah saw sendiri tidak menganggap bahwa segala norma yang berlaku sebelumnya dibatalkan, dan harus dihancurkan untuk membangun agama diatas prinsip yang sama sekali baru. Akan tetapi, prinsip yang digunakan adalah bahwa apa yang sudah diketahui oleh manusia dapat diterima, sementara agama diturunkan untuk memperbaiki urusan mereka yang menyimpang. Firman Allah swtArtinyaJadilah engkau pema'af dan suruhlah orang mengerjakan yangma'ruf, serta berpalinglah dari pada orang-orang yang bodoh.Surat al-A"raf :199 ini yang isinya adalah suruhan untuk berbuat yang baik. Katama,,rūfdidalam ayat ini dapat dipahami sebagai mengandung dua makna, yaitu: dapat bermakna sebagai kebaikan dan praktik yang yang telah mapan yang diakui oleh syara,,, atau bisa juga bermakna sebagai pembatalan dan penolakan terhadap seluruh perbuatan salah dan tidak adil, yang dalam hal ini tentunya tidak ma'rūf. Hal ini kata Turabi adalah basis dari istishāb. Dari konsep istishābtersebut, Hasan Turabi, merumuskan segala sesuatu itu boleh selama tidak ada indikasi yang melarangnya.Hasan Turabi berkesimpulan bahwa prinsip istishāb bersama- 


\section{Epistemologi Pembaharuan Usul Fikih Hasan Turabi}

sama dengan konsep qiyas yang konprehensif(qiyās wāsi,") dapat melahirkan usul fikih yang luas yang mampu melahirkan fikih yang lues dan dinamis yang pada gilirannya dapat menjawab segala permasalahan yang memenuhi kebutuhan kita yang senatiasa berkembang.

\section{Analisis Pembaharuan yang ditawarkan oleh Hassan Turabi}

Sebagaimana yang telah penulis kemukakan ada dua yaitu al-qiyās alwāsi,,dan al-istishāb al-wāsi,,. Al-qiyās al-wāsi,,(qiyas yang luas) merupakan pendapat yang diilhami oleh ulama-ulama usul fikih terdahulu, yang menggunakan qiyas sebagai suatu cara untuk menggali hukum yang tidak dijelaskan dalam Alquran maupun hadis.Hasan Turabi dalam menggunakan qiyas yang lebih luas, nampaknya berbeda dengan rumusan yang digunakan oleh ulama usul fikih terdahulu. Sasaran qiyas yang dimaksud oleh Hasan turabi adalah masalah-masalah yang bersifat umum dan untuk kepentingan umum, bukan masalah nikah, maupun ibadah ritual lainnya. Kalau masalah seperti ini nampaknya Hasan Turabi masih berkiblat kepada rumusan ulama usul fikih terdahulu. Ulama-ulama usul fikihsebelum Turabi didalam menggali hukum yang belum disebutkan oleh Alquran maupun hadis, mereka menggunakan qiyas. Qiyas yang dapat dipergunakan untuk menggali hukum mempunyai rukun-rukun tertentu, yaitu; asal, cabang, „illatdan hukum.

Dalam masalah umum, Hasan Turabi menggunakanistilah yang sama, namun didalam aplikasi metodologinya berbeda dengan ulama usul. Qiyas 


\section{Mas'adah}

yang digunakan oleh Hasan Turabi sebenarnya mengarah kepada maslahah almursalah, karena memangdidalam prosedur penggunaan qiyas, Hasan Turabi berbeda dengan apa yang dilakukan oleh ulama usul. Ulama usul didalam prosedur pemakaian qiyas, adalah adanya kesamaan „illatantara furu"dengan asl. Sedangkan Hasan Turabi didalam penggunaan qiyas, tidakada menyinggung sedikitpun tentang „illat, yang menjadi titik beratnya adalah adanya kemaslahatan bagi umat manusia. Maslahah al-mursalahyang dmaksudkan dalam syari,, at Islam yang disampaikan melalui wahyu yaitu Alquran maupun hadis bertujuan (maqāsid al syari,,ah) untuk kemaslahatan umat manusia. Teori maqāsidsebenarnya sudah ada dikembangkan oleh ulama usul fikih sebelum HasanTuarabi, yaitu asy-Syātibībahkan ulama-ulama sebelum asy-Syātibī juga ada yang menggunakan maslahah al-mursalah,seperti Imam Malik (93-179 H) .

Pembaharuan yang ditawarkan Al-Turabi yang kedua ialah istishābyang luas (al-Istishāb al-Wāsi,,). Konsep istishābini sebenarnya telah digunakan jauh sebelum Al-Turabi sudah digunakan oleh ulama-ulama klasik yaitu Malik,Hanafi, Syafi'i, dan Ahmad bin Hanbal. Al-Turabi hanya menambahkan kata-kata al-wāsi'yang istilah tersebut tidak dipakai oleh ulama-ulama mutaqaddimin. Istishābmenurut pengertian yang dikemukakan oleh ulamaulama usul ialah menganggaphukum sesuatu itu tetap seperti keadaanya semula karena tidak adanya dalil yang melarangnya atau belum adanya dalil 


\section{Epistemologi Pembaharuan Usul Fikih Hasan Turabi}

yang merobahnya

Basis atau lapangan istishābmenurut Al-Turabi ialah tradisi atau adat istiadat yang berlaku di masyarakat yang telah berlaku turun temurun. Selama tradisi tersebut mempunyai nilai ma'rufatau bermanfaat untuk umat manusia dan tidak adanya dalil yang melarangnya hukumnya adalah ibāhah(boleh). Akan tetapi lapangan istishābmenurut ulama usul tidak terbatas kepada mu'āmalah dan tradisi masyarakat yang sudah berlaku saja, akan tetapi merambah kepada hukum-hukum ibadah, seperti seseorang yang sudah berwuduk kemudian ia ragu apakah wuduknya sudah atal atau belum, maka ia dihukumkan tetap masih berwuduk berdasarkanistishāb. Konsep istishāb alwāsi'yang ditawarkan oleh Al-Turabi yang berpendapat bahwa tradisi yang ma'ruf dapat terus berlaku selama belum adanya dalil yang melarangnya juga sudah dipergunakan oleh ulama-ulama usul sebelumyayang menyebutnya dengan uruf șaḥị̣(tradisi yang baik).

Seruan Turabi untuk dilakukannya pembaharuan ilmu ushul fiqh begitu intens-nya disuarakan. Bahkan untuk keperluan ini beliau menyusun sebuah buku monografi bertajuk tajdidu 'ilmi ushul al-fiqh (Pembaharuan Ilmu Ushul Fiqh). Namun jika dicermati lebih dalam, seruan tersebut sesungguhnya kurang menyentuh esensi persoalan. Sebab pembaharuan atau reformasi menuntut adanya tawaran kaidah-kaidah baru sebagai wujud perbaikan dari kaidahkaidah yang sudah melembaga selama ini. Hal ini belum nampak tersuguhkan 


\section{Mas'adah}

secara elaboratif dalam seruannya tersebut. Apa yang dilakukan Turabi sebenarnya seruan moral untuk mengoptimalkan penggunaan ushul fiqh untuk mereformasi bangunan fiqh yang sesuai dengan perkembangan. Mereka mengapresiasi ilmu ushul fiqh sebatas sebagai warisan yang mesti dipelajari dalam bentuknya yang bersih dan murni. Selain itu, keterbatasan metode pengajaran dan kesulitan bahasa yang terdapat pada sebagian sumber-sumber primer ilmu ushul fiqh turut mengondisikan problem pemberdayaan ilmu ini di tengah kehidupan beragama. Karena itu, jika kita menginginkan ilmu ini berkembang pesat secara alami dalam kehidupan beragama maka kita mesti mengubah cara pandang kita terhadap disiplin ilmu ini selain juga harus mengembangkan metode kajian dan pengajaran sesuai konteks perkembangan teknologi informasi dan komunikasi. ${ }^{33}$

\section{Penutup}

Pembaharuan Usul Fikih yang ditawarkan Hasan al-Turabi bukanlah merubah semua rangka Usul Fikih yang telah dibuat oleh ulama-ulama usul, akan tetapi pembaharuan Usul Fikih Hasan al-Turabi hanya menawarkan dua masalah, yaitu:

1. Penggunaan al-qiyās al-wāsi'(qiyas yang luas dan konfrehensif) yang basisnya diambil dari mașālih al-mursalah.Pada prinsipnya syari'at Islam itu datang

${ }^{33}$ Muhammad Roy Purwanto, Teori Hukum Islam dan Multikulturalisme (Jombang: Pustaka Tebuireng, 2016), 1031 


\section{Epistemologi Pembaharuan Usul Fikih Hasan Turabi}

adalah untuk kemaslahatan(kebaikan) umat manusia dan bukan untuk menyengsarakan.

2. Penggunaan istishāb yang luas (al-Istishāb al-Wāsi,,) yang basisnya adalah tradisi atau'uruf yang telah berlaku di masyarakat. Tradisi umat telah ada sebelum syari'at Islam itu datang. Islam diturunkan bukan untuk kehidupan umat manusia berdasarkan kepada ketentuan-ketentuan yang sama sekali baru dan juga bukan untuk menghancurkan secara total ketentuan-ketentuan yang telah berlaku sebelumnya. Tetapi kedatangan Islam adalah untuk menjamin kesinambungan berlakunya praktik dan tradisi yang telah mapan yang sifatnya mencerminkan keadilan dan kebenaran, dan sekaligus memperbaiki serta memodifikasi praktek-praktek yang menyimpang darikeadilan.

Konsep pembaharuan Usul Fikih yang ditawarkan oleh Hasan al-Turabi ini sebenarnya udah dirintis dan dimulai oleh ulama-ulama usul terdahulu. Al-Turabi mengambil istilah qiyāsdan istishāb kemudian menambahinya dengan kata-kata al-wāsi‘ yang basisnya tidak jauh berbeda dengan pendapat ulama-ulama usul sebelumnya. Menurut penulis konsep Al-Turabi tersebut bukanlah hal yang baru tetapimasalah klasik yang sudah dibahas oleh ulama-ulama Usul Fikih sebelum Al-Turabi lahir. 


\section{DAFTAR PUSTAKA}

Ahmad ibn Hanbal, Musnad al-Imam Ahmad Ibn Hanbal, Beirut: Dar al-Kutub alIslamiyah, 1993, vol.IV, .

Al As'adi, Muhammad Ubaidillah, al-Mujiz Fi Ushul al-Fiqh, Tth: Dar asSalam, 1990

al-Azdī, Abī Dāwud Sulaimān ibn al-Asy, ,aś as-Sijistāny, Sunan Abī Dāwud Indonesia:Maktabah ahlān,t.t, Jil IV, 109

Al Balajy, 'Abd as-Salām al-Balājy,Tatawwur 'Ilm Usul al-Fiqh wa Tajaddudahu, T.t.p: Dār al-Wafā', 2007/1428

al-Ghazali, Abu Hamid al-Ghazali, al-Mustashfa Fi Ilm al-Ushul Beirut: Dar al-Kutub alllmiyah, 1993

AlIsnawy, Abdurrahim al-Isnawy, Nihayah al-Sul syarh minhaju al-wushul, Beirut: Dar al-Kutub al-Ilmiyah, 1999

Al Qarafy, Abu al-Abbas Ahmad ibn Idris ,Syarh Tanqih al-Fushul, Al-Faniyah alMuttahidah, cet. 1, 1973

Al Sais, Muhammad Ali, Nasy'ah al-Figh al-Ijtihadi wa Athwarih, Ttp: Mujma' al-Buhus al-Islamiyah, 1970

Al Turabi, Hasan, Fiqih Demokratis, terj. Abdul haris dan Zimul Aim, Jakarta, Arasy, 2003

Qadaya al-Tajdid: Nahwu Minhaj Usuli, Ma'had lil Buhus wa alDirasah al-Ijtima'iyyah, t.t,

Amstrong Karen, Berperang demi Tuhan Fundamentalisme Dalam Islam, Kristen, dan Yahudi , Bandung: PT Mizan Pustaka, 2004

asy-Syawkānī , Muhammad ibn Alī ibn Muhammad asy-Syawkānī, Irsyād al-Fuhūl Beirut:Dār al-Kutub al-„,Arabiyah tt

Muhammad bin 'Aly bin Muhammad, Nail al-Awtār Mesir: Muṣtafā alBāb al-Halaby, t.t ,Jil IV

A.Yazid, " Epistimologi Ushul Fiqh:Antara Pembaharuan dan Pemberdayaan Mekanisme Istinbath Al-Ahkam", Jurnal Asy-Syir'ah,No.1 Vol.45, 2011

al-Zabīdī Muhammad ibn Muhammad al-Husainī, Ittihāf as-Sādah al-Muttaqīn Beirut:Dār al-Kutub al-„Ilmiyah, 1989 Jil I

Departemen Agama RI, Al-Qur'an dan Terjemahnya, Jakarta: Maghfirah Pustaka, 2006

Guralnik, David B.Guralnik, Websters New World Dictionary of the American Language, New York: Warners Book, 1987

30 | Dinamika Vol. 3, No. 1, Juni 2018 


\section{Epistemologi Pembaharuan Usul Fikih Hasan Turabi}

Hatta, Moh. "Pemikiran Hukum Islam Hasan Al-Turabi", Darussalam Jurnal Pendidikan, Komunikasi, dan Pemikiran Hukum Islam UIN Sunan Ampel Surabaya, No.1 Vol 7, September 2015.

Idris, Julbadri Pembaharuan Islam pada masa periode Modern, dalam Jurnal media Dinamika, No. 29 tahun XIV/ 1998

Madjid, Nurcholis Islam Doktrin dan Peradaban, Jakarta: Paramadina, 1992

Mahluf, Luois al-Munjid F̄̄ al-Lugah wa al-A,lām, Beirut: Dār al-Masyriq,1986

Maulana Muhammad Ali, The Religion Of Islam, Cairo: The Arab Writer Publisher \& Printers, t.t,

Mizani, Saiful, (ed), Islam rasional gagasan dan Pemikiran, frop. Drs. Harun Nasution, Bandung: Mizan, 1996,

Nasution Harun, Pembaharuan dalam Islam, Sejarah Pemikiran dan Gerakan, Jakarta: Bulan Bintang, 1994

Purwanto, Muhammad Roy Purwanto, “Nalar Qur'ani al-Syafi'i dalam Pembentukan Metodologi Hukum: Telaah Terhadap konsep Qiyas", dalam An-Nur: Jurnal Studi Islam, Vol. 1, No.1, September 2004.

Roy, Muhammad, Ushul Fiqih Madzhab Aristoteles: Pelacakan Logika Aristoteles dalam Qiyas Ushul Fiqih, Yogyakarta: Safiria Insania Press, 2004

Rais, M. Amin, “Kata Pengantar”, dalam Jhon J Donohue dan Jhon L. Esposito (eds), Islam dan Pembaharuan: Ensiklopedi Masalah-masalah, terj. Machnun Husein. Jakarta: Rajawali Press, 1993

Sya'bān Muhammad „Ismā,,īl, at-Tajdīd Fī Usūl al-Fiqh, Mekah:Maktabah alMakkiyah,2000

Yuslem, Nawir, Gerakan Hasan Turabi Tentang Tajdīd Usūl Al-Fikih, dalam Analytica Islamica, Vol.3 No.1, Mei 2001

Zahrah, Muhammad Abū, Usūl al -Fiqh, Kairo:Dār al-Fikr al-„,Arabī,t.t. 
Mas'adah

32 | Dinamika Vol. 3, No. 1, Juni 2018 